\title{
GRZEGORZ ZARAZIŃSKI
}

\section{Czy mediom potrzebna jest etyka?}

Rozwój techniki nie przekłada się jedynie na postępującą likwidację problemów z różnych dziedzin życia, lecz stawia często przed nowymi pytaniami. Przy podejmowaniu rozstrzygnięć dla których nie istnieja jednoznaczne normy zachowań tym bardziej pojawia się konieczność szukania nowej orientacji, nowych metod reagowania na zmieniające się warunki życia. Aby działanie czlowieka było zorientowane na dobro, potrzeba mu etyki czyli pogłębionej refleksji nad własnym dzialaniem.

W potocznym rozumieniu, takie pojęcia jak etyka, moralność stosowane sa zamiennie. Dla potrzeb naukowej dyskusji należy przypomnieć fundamentalna różnicę i rozróżnienie pomiędzy etyką a moralnością. Moralność to zbiór wartości, norm i regul, które regulują relacje pomiędzy członkami społeczności i są fundamentem świadomego lub nieświadomego dzialania. Jest ona różna od innych dziedzin życia, jak sztuka, prawo, gospodarka czy religia. Etyka jest naukową refleksją nad moralnością. Jej zadanie wykracza poza empiryczne badania tego, co w spoleczeństwie uważane jest za działanie moralne i shuszne (etyka opisowa). Jako dziedzina nauki, wywodzaca się z filozofii praktycznej, ma charakter nauki normatywnej i centrum jej zainteresowania stanowi uzasadnienie sądów i wartości moralnych za pomocą logiki i rozumowych zasad argumentacji (etyka normatywna). Zasady etyczne, jako zgodne z rozsądkiem i uważane za ogólnie ważne, dają wskazania co do wlaściwego postępowania.

\section{Aktualność badań}

Dyskusje o odpowiedzialności mediów sięgają początku XVII w. gdy powstała prasa i pojawily się pierwsze oskarżenia o prasowe manipulacje. Pojęcie 
etyki w kontekście mediów zastosowano jednak dopiero pod koniec XIX w. w tytule anglojęzycznej publikacji Ethics of Journalism (1889 r.), poświęconej krytyce prasy. Wobec fenomenu powstania prasy masowej i takich zjawisk, jak propaganda i manipulacja, rosla świadomość możliwych niebezpieczeństw, które niesie ze soba dalszy rozwój mediów. Tematy budzace wówczas zainteresowanie, nie stracily na swej aktualności: manipulacja opinią publiczna, ochrona prywatności i kategorie opisujące ideal służby prawdzie poprzez obiektywność dziennikarskiego warsztatu. W 1910 r. związek wydawców w Kansas (USA) po raz pierwszy wprowadził Ethikkodex dla dziennikarzy, a dziesięć lat później etyka mediów byla już wykładana na amerykańskich uniwersytetach. Tym samym dyskusja o problemach prasy i radia znalazla swoje miejsce w kanonie dziedzin nauki. Rozwój w kierunku empiryzmu i żądanie nauki wolnej od wartości spowodowal jednak, że naukowy dyskurs o normach i wartościach etyki mediów zostal stopniowo zepchnięty na margines ${ }^{1}$. Po II wojnie światowej impulsem dla kolejnych badań było opublikowanie w USA raportu tzw. Hutchins Commission (od nazwiska jej przewodniczacego Roberta Hutchinsa - rektora Uniwersytetu w Chicago). Podjęta przez komisję sprawa odpowiedzialności spolecznej prasy, stała się tematem licznych debat. Okazją do powstania raportu byla obawa o rozszerzanie się nierzetelnego dziennikarstwa i doniesień pelnych sensacji i plotek bez wartości dla życia spolecznego. Komisja żądała większej orientacji w kierunku dobra wspólnego, większego zainteresowania wydarzeniami i tematami ważnymi dla kultury, polityki i gospodarki, a także stworzenia w mediach szerokiej platformy wymiany poglądów i prezentacji różnych grup społecznych. Etyka mediów lub etyka dziennikarska znalazła odtąd na stałe miejsce w kanonie nauk uniwersyteckich, nie tylko w USA, ale także i na świecie.

Dziś okazją do dyskusji o etyce mediów są najczęściej negatywne wydarzenia budzace duże zainteresowanie u odbiorców, którzy widza w nich naruszenie przez media pewnych norm współżycia społecznego. Do nich można zaliczyć celowe lub nieświadome wprowadzanie w bląd opinii publicznej (np. w $1991 \mathrm{r}$., w czasie wojny w Zatoce Perskiej, amerykańska stacja CNN zostala wciagnięta w informacyjny sabotaż wlasnego spoleczeństwa przez armię), różne formy prezentacji sensacji dziennikarskiej, jak tragiczne wypadki czy śmierć (zdjęcia zastrzelonego dziennikarza Waldemara Milewicza), prowokacja dziennikarska lub zachowanie dziennikarza $\mathrm{w}$ obliczu przestępstwa (ekskluzywne wywiady $\mathrm{z}$ ukrywającymi się przestępcami), naruszanie prywatności życia (w 1997 r. polowanie na sensacyjne zdjęcia zakończyło się tragicznym wypadkiem w Paryżu i śmiercią księżnej Diany), kupowanie artykulów, czy też ekscesy w programach rozrywkowych (Big Brother).

${ }^{1} \mathrm{~S}$. We i s c h e n b e r g: Handbuch Journalismus und Medien. Konstanz 2005 s. 212. 


\section{Zakres konfliktów}

Zasady etyczne są mocno związane z określonym środowiskiem i powstaja jako polączenie pojedynczych norm. Istnienie moralności środowiskowej ma o tyle pozytywny wplyw, że scala wewnętrznie grupę, umacnia jej tożsamość i nadaje jej pewną stabilność. Ponadto szczególna forma tworzenia się moralności w danym środowisku nadaje jej charakter na tyle elastyczny, że pozwala stosunkowo szybko reagować na historyczne i społeczne zmiany, a tym samym zapewnia względną historyczną trwalość ${ }^{2}$.

$\mathrm{Na}$ tym tle środowisko dziennikarskie przedstawia się jako rzeczywistość niezmiernie zlożona. Samo w sobie bardzo heterogenne, ulega ciaglym przemianom, co znacznie utrudnia sformulowanie jednoznacznego kodeksu zachowań. Jest to także jeden z powodów braku wypracowania przez środowisko dziennikarskie jednolitej reprezentacji i norm zawodowych.

Dodatkowym utrudnieniem jest fakt, że obszary dziennikarskiego dzialania zachodzą na siebie w wielu miejscach, mimo że teoretycznie sa zawodowo rozdzielone. Dziennikarskie działanie odbywa się zwykle na kilku poziomach. Poziom podstawowy tworzą dziennikarze $w$ terenie. To oni relacjonują wydarzenia, szukaja świadków, ekspertów. Gotowy materiał trafia do redaktora, który decyduje o wyborze i kolejności tematów, rozdziela zadania, dokonuje korekty materialu i dopasowuje go profilu swojej gazety lub programu. Redaktor naczelny decyduje wraz $z$ wydawca o profilu programu lub gazety i wyznacza zakres i treść kompetencji dla podleglych mu pracowników. Inną rolę mają komentatorzy, którzy do wiadomości dodają komentarz. To oni mają przywilej nadawania materiałowi określonego charakteru i przez swój komentarz potrafią tworzyć uczucie sympatii lub odrzucenia wiadomości. Jak $z$ tego pobieżnego opisu widać, stopień organizacji systemu, która określa pracę dziennikarza jest na tyle wysoki, że jego indywidualna autonomia może być rozpatrywana jedynie w perspektywie pracy zespolowej. Stąd też, wychodząc poza potoczne i wąskie rozumienie pojęcia etyka dziennikarska stwierdzić należy, że odpowiedzialność za etyczne dzialanie ma charakter strukturalny i spoczywa ogólnie na ludziach pracujacych w mediach - także na wlaścicielach tytułów czy stacji, wydawcach i redaktorach.

Obok ogólnego opisu pracy dziennikarskiej trzeba zwrócić uwagę na różnorodność mediów, w których pracują dziennikarze, co z kolei wymaga szczególnej specjalizacji. Radio ma inne wymagania od telewizji lub tygodnika; pojawiają się

${ }^{2}$ R. L e s c k e: Von der Medienethik zur Analyse normativer Muster der Medienproduktion. W: G. R u s c h (red.): Einführung in die Medienwissenschaft. Wiesbaden 2002 s. 209. Patrz także B. Golka, B. Michalski: Etyka dziennikarska a kwestie informacji prasowej. Warszawa 1995; W. L. R i ver s, C. Ma th e w s: Etyka środków przekazu. Warszawa 1995. 
nowe specjalizacje, np. redaktor gazety internetowej. Również pewne formy dziennikarskiej pracy ulegają przemianom, np. tendencja do lączenia informacji z rozrywką (Infotainment). Każde z mediów konfrontuje dziennikarza z innym zakresem konfliktów. W ostatnich latach zaobserwować można wzajemne upodabnianie się mediów, mimo ich różnorodności. Wiodąca rola telewizji powoduje ksztaltowanie się swoistej telewizyjnej estetyki w innych mediach. Gazety, które rano sprzedają sensacyjne wiadomości za pomocą ekspresyjnych, nieproporcjonalnie dużych zdjęć sa bliższe medium telewizji niż prasowym tygodnikom. Wszystko to pokazuje, jak dynamiczny jest zakres dzialania dziennikarzy. Mimo takiej sytuacji nie można pomijać pytania, dotyczacego roli i zakresu odpowiedzialności indywidualnej. Należy pytać, kto, z jakim uzasadnieniem, i za jakie formy dziennikarskiej pracy ponosi lub powinien ponosić odpowiedzialnośc $c^{3}$.

Klaus Wiegerling, niemiecki etyk, wskazuje na możliwe obszary konfliktów etycznych we wspólczesnym dziennikarstwie. Wylicza następujące:

- Korupcja. Pojawiaja się przypadki bezpośredniego przekupstwa, ale częściej spotykanym zjawiskiem jest rezygnacja ze swojej niezależności i niezawislości. Coraz bardziej rosnący nacisk na aktualność i wyścig o pierwszeństwo w zdobywaniu informacji, powoduje rezygnację $z$ ukazania głębszego tla wydarzenia. Dziennikarze chętnie korzystają z materialów działu PR firmy i nie troszczą się o obiektywizm w ich przedstawianiu. Duże staje telewizyjne za cenę dostępu do wyjatkowych wydarzeń, jak np. wojna w Zatoce Perskiej, rezygnuja z krytycznych doniesień. Korupcja może mieć także charakter wewnatrzredakcyjny, gdy dziennikarz, znając określoną strategię informacyjną redakcji, dokonuje w swoim materiale mniej czy bardziej świadomej autoingerencji cenzorskiej. Niektóre strefy przemilczeń w prezentowanym materiale są skutkiem (ubocznym) przyjętej przez redakcję opcji. Inne natomiast są wprost zamierzone jako obowiązujace w środowisku. Tego typu ograniczenia latwiej ukazać, kiedy uświadomi się, jakie konkretne zadania stoja przed danym środkiem przekazu w odniesieniu do całej spoleczności.

- Sensacja. Wzrastajacy nacisk na sukces ekonomiczny (pozyskiwanie reklamodawców i odbiorców, wzrost nakladu) powoduje, że rola dostarczyciela informacji schodzi na dalszy plan, natomiast eksponowane są uczucia i sensacje. Tym samy obraz rzeczywistości u odbiorcy staje się zafalszowany. Ludzie, którzy swój obraz świata czerpią z lektury tabloidów i bulwarowej prasy, czują się bardziej niepewni i zagrożeni w swoim życiu. Argument, że czytelnicy lub odbiorcy wlaśnie tego pragna, wylacza całkowicie kwestie moralności i etyki z dzialania mediów i calą odpowiedzialność przerzuca na odbiorców.

${ }^{3} \mathrm{~S}$. We is c h e n b e r g: Handbuch Journalismus und Medien. Konstanz 2005 s. 212. 
- Naruszenie prywatności. Caly dzial prasy zajmuje się doniesieniami z życia różnych sfer - nie tylko z życia polityków i gwiazd show-biznesu. Czyni z nich tematy do codziennych dyskusji. Sfera prywatna już nie jest strefą tabu, lecz bardziej wyzwaniem do jej odkrywania.

- Aktualność. Kluczowym problemem dzisiejszego dziennikarstwa jest pogoń za nową informacja. Techniczne rozwiązania dają możliwość bycia na żywo (live) wszędzie tam, gdzie dzieją się rzeczy ważne. Bezpośrednie transmisje na żywo powoduja u odbiorcy wrażenie obiektywności i autentyczności, podnosząc jednocześnie poziom nieprzewidywalności. Spod przymusu aktualności uwolniona jest prasa. Spotyka się jednak coraz częściej internetowe wydania gazety, które sa uaktualniane kilka razy dziennie. Wiadomość jest mierzona poprzez swoją aktualność. Istota jej rzeczywistej przydatności pozostaje często marginalnym przekazem.

- Urynkowienie. Wraz z szerokim wejściem na rynek nadawców prywatnych i konkurencji pojawil się problem urynkowienia dziennikarstwa. Pojęcie „misja”, ,powolanie" zastapione zostalo przez pojęcie dziennikarskiego zawodu. Także media publiczne ulegają naciskom rynku. Powoduje to powstawanie oferty medialnej, która jak najmniejszym kosztem chce pozyskać coraz większą liczbę odbiorców. Propozycje pojawiające się w środowiskach dziennikarstwa internetowego, aby wysokość honorarium autorskiego uzależniona byla od liczby wywolań danego artykulu na stronie przegladarki, może powodować, że praca dziennikarza bardziej będzie zorientowana na sukces rynkowy, niż na wartość samej informacji ${ }^{4}$.

\section{Relacja etyki do prawa}

Etyka mediów jest dzialem etyki stosowanej, obok etyki lekarskiej, etyki gospodarczej i innych. Etyka stosowana jest konieczna wówczas, gdy rozwój techniczno-naukowy otwiera nowe możliwości działania, a tym samym pojawiają się nowe problemy, dla których dotychczasowe zasady moralne nie znajdują kryteriów zachowań. Etyki mediów domagają się szczególnie ci, którzy w rozwoju mediów - czwartej wladzy, widzą nie tylko szanse dla rozwoju demokracji i jednostki, ale i niebezpieczeństwa. Na czym te szanse i zagrożenia polegaja jest zadaniem empirii. Amerykański slogan z XIX w. publish and damned (drukuj bez względu na skutki), nie ma obecnie żadnej racji bytu. Problem odpowiedzialności i uczciwości stal się więc znacznie ważniejszy niż przed laty. Rola etyki mediów sprowadza się zatem do zwracania uwagi na kondycję czlowieka

\footnotetext{
${ }^{4} \mathrm{~K}$. W i e g e r l in g: Medienethik. Stuttgart 1998 s. $158 \mathrm{nn}$.
} 
(np. ochrona dzieci i młodzieży) i pomocy w realizacji szans oraz minimalizowania niebezpieczeństw w procesie jego calościowego rozwoju ${ }^{5}$.

Należy podkreślić, że w relacji etyka - prawo argumentacja etyczna odnosi się do tych osób lub instytucji, które się zobowiazaly do etycznego działania. Prawo, jako zespól norm i dyspozycji regulowanych przez państwo, odnosi się do wszystkich obywateli, nie tylko np. do dziennikarzy. Może się zdarzyć, że normy prawa zbieżne będą z zasadami etycznymi (np. zakaz oszczerstwa). Zasadnicza różnica pomiędzy etyką a prawem polega więc na tym, że wszystkie zasady etyki mediów, kodeksy honorowe obowiązują w sumieniu, zaś ich przestrzeganie zależy od akceptacji lub odrzucenia przez środowisko ludzi pracujacych w mediach $^{6}$.

Konieczność istnienia etyki mediów pokazuje praktyka prawna, która reaguje na już „rozpoznane” niebezpieczeństwa, ma więc charakter retrospektywny. Prawodawca nie zawsze nadaża za postępem technicznym i rodzacymi się z niego watpliwościami, co do norm postępowania. Współczesne media, a szczególnie Internet, maja charakter globalny. Widać już pewne próby międzynarodowej regulacji prawnej, ale skuteczna kontrola okazuje się być niemożliwa. Pewne grupy mają charakter zamknięty (Intranet, Chat), co z natury wyklucza kontrolę państwa. Widać jednak wśród nich powstawanie norm zachowania - netykietę (zbiór zasad obowiąujących w Internecie), w mniej czy więcej skodyfikowanej formie FAQ. Etyka medialna w odróżnieniu do prawa ma więc charakter perspektywiczny, daje orientacje w szybkim procesie tworzenia nowych form komunikacji, programów czy modyfikacji metod pracy dziennikarskiej. ${ }^{7}$

\section{Perspektywa indywidualna i społeczna}

Etyka mediów odnosila się dhugie lata bezpośrednio do pojedynczego dziennikarza, stąd przez dominowala perspektywa etyki indywidualistycznej. Szereg prac badawczych dowiodlo glębszego podloża problemu i wskazalo, że w świecie mediów dziennikarze tworzą ważny, ale nie jedyny element wplywajacy na ksztalt i treść przekazu, ponoszacy za to etyczną odpowiedzialność. Doświadczenie pokazuje, że kryteria wyboru i tworzenia przekazu dziennikarz nabywa w

${ }^{5} \mathrm{R} . \mathrm{F}$ u n i o k: Medienethik und der Wertediskurs über Medien. W: M. K a r m a s in (red.): Medien und Ethik. Stuttgart 2002 s. 41.

${ }^{6}$ L. Brajnović: Kodeksy deontologii dziennikarskiej. W: Z. K o by lanska, R. D. Grabowski: Dziennikarski etos. Z wybranych zagadnien deontologii dziennikarskiej. Olsztyn 1966 s. 16.

${ }^{7}$ R. Funiok, dz. cyt., s. 43 
trakcie procesu dziennikarskiej socjalizacji tzn. w kontekście ksztalcenia, a szczególniej praktyki redakcyjnej ${ }^{8}$.

Perspektywa spoleczno-etyczna akcentuje bardziej odpowiedzialność zbiorową i podkreśla, że warunki i przestrzeń podejmowanych decyzji przez jednostkę jest uwarunkowana przez strukturalny $i$ organizacyjny kontekst ich środowiska. Jak już to zostało wskazane powyżej, dziennikarstwo to nie zbiór pojedynczych jednostek, ale cala struktura powiązana relacjami z calym spolecznym systemem. Ten system musi być na tyle moralnie wrażliwy, że jednostka może zachowywać się moralnie.

Przez dlugi okres etyka jednostki byly zdecydowanie na pierwszym miejscu, obecnie, w ramach umacniania się teorii systemu, na pierwszy plan wysuwa się perspektywa socjalno-etyczna, przy czym zaniedbuje się odpowiedzialność jednostki. Jednak obie perspektywy mają dla ludzi pracujacych w mediach, a także i dla odbiorców równie ważne znaczenie. Dziennikarska etyka zawodowa jest wynikiem osobistej moralności i warunków pracy. Dla wysokiego standardu dziennikarskiego rzemiosla potrzeba nie tylko ogólnego kodeksu dla środowiska dziennikarskiego, apeli o indywidualną odpowiedzialność, ale także ważnego trzeciego elementu, jakim sa - oparte na moralnych zasadach - wewnętrzne przepisy i statuty, regulujące pracę w redakcji i innych instytucjach mediów masowych $^{9}$.

\section{Trzy podmioty odpowiedzialności}

Obecnie problem odpowiedzialności w mass mediach stal się jednym z ważniejszych zagadnień. Dziennikarstwo amerykańskie mówi o nowej odpowiedzialności, która wobec bardziej wymagającego odbiorcy budzi konieczność profesjonalizmu wyrażającego się w kodeksach, fachowym ksztalceniu i organizowaniu życia zawodowego. Jest to również warunek zachowania wolności prasy dla przyszlych pokolen ${ }^{10}$. Apel o odpowiedzialność w procesie tworzenia, dystrybucji i odbioru mediów kierowany jest kolejno do trzech grup: dziennikarzy i

${ }^{8}$ O konieczności szerszego ujęcia odpowiedzialności etycznej mówi już wstęp do dokumentu Papieskiej Rady ds. Środków Spolecznego Przekazu: Etyka w środkach spolecznego przekazu z czerwca 2000 roku, gdzie zwraca się uwagę, że decyzje etyczne podejmowane sa zwlaszcza przez tych, którzy sprawuja kontrole nad narzędziami spolecznego przekazu, ksztaltujac ich struktury, zasady dzialania i treści. Należa do tej grupy urzędnicy publiczni i dyrektorzy przedsiębiorstw, czlonkowie rad zarzadzajacych, wlasciciele, wydawcy i kierownicy stacji nadawczych, redaktorzy, osoby odpowiedzialne za programy informacyjne, producenci, autorzy tekstów, korespondenci $i$ inni ( ESP 1)

${ }^{9}$ R. Funio k, dz. cyt., s. $47 \mathrm{nn}$.

${ }^{10}$ W. L. Rivers, C. Mathew s, dz. cyt., s. 41. 
ludzi pracujących w mediach, wydawców i wlaścicieli stacji nadawczych i wreszcie do samych odbiorców.

Dziennikarze i ludzie pracujacy w mediach (redaktorzy, autorzy, korespondenci, agencje informacyjne) maja swój wkład w etyczny rozwój mediów, o ile w swojej pracy kierują się zasadami profesjonalizmu zawodowego, a więc rzetelnościa, bezstronnościa, poszukiwaniem prawdy, obiektywizmem. Nie chodzi tutaj o same pojęcia, lecz o wypelnienie ich konkretną treścia, w konkretnym środowisku czy redakcji. Dziennikarski, indywidualny imperatyw powinien być wspierany przez środowiskowe kodeksy, które precyzuja na jakich zasadach opiera się praca w danej stacji, u określonego wydawcy, jaką treścią sa te zasady wypelnione. Tak pojedynczy ludzie, jak i cale środowiska medialne powinny liczyć się z krytycznymi glosami opinii czy to pojedynczymi, czy to opinii zorganizowanej w spolecznych instytucjach monitoringu mediów.

Wydawcy prasowi i wlaściciele stacji stoją przed koniecznością wypracowania takich środowiskowych kodeksów zasad postępowania i stworzenia organizacyjnych struktur samokontroli, że określą one przestrzeń moralnego dzialania dla osób pracujących w mediach.

Odbiorcy to trzecia i liczebnie najsilniejsza grupa. Jako tworzacy opinię publiczna, maja za zadanie krytycznie reagować na ofertę programową odwolujac się do spontanicznego odzewu, zorganizowanych instytucji lub organizacji reprezentujących odbiorców, które zajmują się monitoringiem programu i analizą jego rozwoju.

Ta odpowiedzialność odbiorcy nie leży wyłącznie w gestii jednostki. Korzystanie z mediów odbywa się przecież w pewnym spolecznym kontekście, skoro w rodzinie, w szkole dyskutuje się o treści i jakości programu. Celowym jest tworzenie grup czy organizacji, które w interesie odbiorców sa krytycznymi partnerami dla dwóch wymienionych wcześniej grup.

\section{Instytucje i kodeksy etyczne}

Jeżeli etyka mediów ma mieć znaczenie praktyczne, musi spelnić określone wymagania. Potrzebuje teoretycznych podstaw, precyzyjnego określenia pola dzialania, uwzględnienia zmian dokonujacych się w systemie medialnym oraz zrozumialego sposobu jej wyrażania. Refleksja nad etycznym dzialaniem powinna stale towarzyszyć procesowi dziennikarskiej socjalizacji, począwszy od nauki zawodu po późne lata doświadczeń. Oczekiwania, cele, zadania, doświadczenia calych środowisk, a nierzadko pokoleń dziennikarskich znalazły swoją trwała 
formę w postaci kodeksów dziennikarskich - podstawowych instrumentów samokontroli i określania jakości dziennikarskiej pracy. Przykładowo reguly pracy w mediach regulują na szczeblu międzynarodowym kodeksy Międzynarodowej Federacji Dziennikarzy (Bordeaux 1954), Międzynarodowej Konferencji Związków Dziennikarskich (Praga 1983) Deklaracja o Mediach UNESCO (Paryż 1978) czy też kodeksy krajowe, np. Zasady Niemieckiej Rady Prasy (1979). Te kodeksy i deklaracje mają wiele zbieżnych punktów ${ }^{11}$. Należą do nich, m.in.:

- apel o świadomość odpowiedzialności dziennikarzy przy wypełnianiu ich spolecznego zadania,

- żądanie niezależności w przykazywaniu wiadomości,

- szacunek wobec prawdy,

- uczciwość w zdobywaniu i przykazywaniu informacji,

- obowiazek sprostowania falszywej wiadomości,

- zachowanie tajemnicy dziennikarskiej,

- szacunek wobec prywatności osób,

- zaangażowanie na rzecz pokoju i praw czlowieka,

- niemożliwość pogodzenia dziennikarskiego etosu z przyjmowaniem korzyści majatkowych.

W Polsce tymi zagadnieniami zajmuje się Komisja Etyki działająca przy TVP. Istnieją kodeksy trzech organizacji dziennikarski, a także Karta Etyczna Mediów.

Komisja Etyki przy TVP, powołana do orzekania o zgodności posteppowania dziennikarzy z zasadami etyki, powstala w maju $1996 \mathrm{r}^{12}$. W sklad Komisji Etyki wchodzi osiem osób reprezentujących jednostki dzialające w ramach TVP, jak i stowarzyszenia twórcze. Rozpatruje ona skargi i zażalenia na niezgodne z zasadami etyki postępowanie dziennikarza, składane przez środowisko dziennikarskie, jak i samych telewidzów. Jej orzeczenia przekazywane sa do wiadomości przełożonych, a ci zobowiazani są do poinformowania Komisji, jakie kroki podjęli w stosunku do podwladnego. W swoim orzecznictwie Komisja kieruje się Zasadami Etyki Dziennikarskiej w TVP S.A. Obejmują one, m.in. zadania dziennikarza telewizji publicznej wobec odbiorców:

- Dziennikarz telewizyjny informuje - w dziennikach i innych programach informacyjnych - o tym, co dzieje się w kraju i na świecie bez narzucania własnego osądu. Odbiorcy sami powinni móc wyrobić sobie opinię na podstawie podanych im w sposób bezstronny i rzetelny informacji i wyjaśnień.

\footnotetext{
${ }^{11} \mathrm{~S}$. We i s c h e n ber g, dz. cyt., s. 218.

${ }^{12} \mathrm{http}$ ://www.tvp.pl/etyka/ z dn. 22.01.2005.
} 
- Dziennikarz telewizyjny wprowadza również odbiorców w debatę publiczna, toczące się w życiu publicznym dyskusje czy także spory bez opowiadania się za jedną ze stron.

- W tzw. najlepszym czasie antenowym powinno znaleźć się miejsce na ważne spolecznie programy, wymagajace od odbiorcy skupienia $i$ uwagi.

Następnie zasadę rozdziału informacji od komentarza. Informacja powinna być rzetelna, dokladna i bezstronna:

- Rzetelność informacji to ścisle podanie faktów, przy czym relacja musi opierać się na źródlach godnych zaufania, zawsze identyfikowanych. Należy bardzo wyraźnie rozróżniać fakty, przypuszczenia, pogłoski.

- Dokladność to nie tylko przedstawienie pojedynczych faktów, lecz także staranie się o to, by dotrzeć do sedna sprawy, ukazanie jej w szerszym kontekście czasowym i przyczynowym.

- Bezstronność zaklada zrównoważone przedstawienie stanowisk i racji wszystkich stron.

Podkreśla się także konieczność należytej staranności w procesie zbierania i opracowywania materiałów:

- Zbieranie materiałów do opracowywanego programu, rejestrowanie informacji, wypowiedzi, wywiadów powinno się odbywać w sposób uczciwy, zgodny z obowiazujacymi normami prawnymi i dobrymi obyczajami.

- Niedopuszczalne jest poshugiwanie się metodami moralnie nagannymi, takimi jak wprowadzanie rozmówcy w bląd, podszywanie się pod inne osoby, ukrywanie rzeczywistego charakteru nagrywanej rozmowy, a także molestowanie lub zastraszanie.

Wreszcie bierze się pod uwage przedstawianie scen przemocy:

- Decyzja o pokazaniu w programie scen przemocy, wojen czy katastrof musi być w każdym przypadku poprzedzona starannym rozważeniem argumentów za i przeciw, nigdy zaś nie może stanowić rutynowej czynności. W grę moga też wchodzić względy pedagogiki spolecznej: chęć wywolania wspólczucia dla ofiar, a z drugiej strony - potępienie sprawców nieszczęścia czy cierpień innych osób.

- Należy brać pod uwage oslabianie wrażliwości etycznej odbiorców, szczególnie dzieci, niebezpieczeństwo banalizacji zła. Skoro zlo jest powszechne, otacza nas na każdym kroku, to może zrodzić się przekonanie, że widocznie tak być musi, taki jest nasz świat, nie ma co się oburzać! Trzeba zatem uwzględniać obawę przed wywolaniem zachowań naśladowczych. 
Kartę Etyczną Mediów, opracowana z inicjatywy Stowarzyszenia Dziennikarzy Polskich, podpisali w dniu 29 marca 1995 r. prezesi: Stowarzyszenia Dziennikarzy Polskich, Stowarzyszenia Dziennikarzy Rzeczpospolitej Polskiej, Katolickiego Stowarzyszenia Dziennikarzy, Syndykatu Dziennikarzy Polskich., Związku Zawodowego Dziennikarzy, Unii Wydawców Prasy, Telewizji Polskiej S.A., Telewizji "Polsat"., Stowarzyszenia Niezależnych Producentów Filmowych i Telewizyjnych, Polskiego Radia S.A., Stowarzyszenia Radia Publicznego w Polsce, Stowarzyszenia Polskiej Prywatnej Radiofonii, Zwiazku Zawodowego Dziennikarzy Radia i Telewizji oraz krajowy duszpasterz środowisk twórczych, ks. Wieslaw Niewęglowski ${ }^{13}$.

Dla orzekania w sprawach przestrzegania Karty i dokonywania interpretacji jej zapisów, sygnatariusze powołali w 19 czerwca 1996 r. Radę Etyki Mediów. Zobowiązali się jednocześnie do upowszechnienia treści Karty, informacji o prawie składania skarg do Rady i niezwlocznego oglaszania orzeczeń Rady. W trakcie swojej dzialalności Rada wydała oświadczenia w sprawach m.in.: programów i artykulów zawierających opis oraz ocenę patologii spolecznych z wyszczególnieniem drastycznych momentów (Oświadczenie z dnia 25 marca 1999 r.), treści demoralizujących oraz wulgarnego języka w telewizji (Oświadczenia z dnia 15 stycznia 2001 r.), prezentacji zdjęć zabitego dziennikarza Waldemara

\section{${ }^{13}$ KARTA ETYCZNA MEDIÓW}

Dziennikarze, wydawcy, producenci i nadawcy szanując niezbywalne prawo człowieka do prawdy, kierując się zasadą dobra wspólnego, świadomi roli mediów w życiu czlowieka i społeczeństwa obywatelskiego przyjmują tę Kartę oraz deklaruja, że w swojej pracy kierować się będa następującymi zasadami:

Zasadą prawdy - co znaczy, że dziennikarze, wydawcy, producenci i nadawcy dokladają wszelkich starań, aby przekazywane informacje byly zgodne z prawda, sumiennie i bez znieksztalceń relacjonują fakty $\mathrm{w}$ ich właściwym kontekście, a w razie rozpowszechnienia błędnej informacji niezwlocznie dokonują sprostowania

Zasadą obiektywizmu - co znaczy, że autor przedstawia rzeczywistość niezależnie od swoich poglądów, rzetelnie relacjonuje różne punkty widzenia.

Zasadą oddzielania informacji od komentarza - co znaczy, że wypowiedź ma umożliwiać odbiorcy odróżnianie faktów od opinii i poglądów.

Zasadą uczciwości - co znaczy działanie w zgodzie z wlasnym sumieniem i dobrem odbiorcy, nieuleganie wpływom, nieprzekupność, odmowę dzialania niezgodnego z przekonaniami.

Zasadą szacunku i tolerancji - czyli poszanowania ludzkiej godności, praw dóbr osobistych, a szczególnie prywatności i dobrego imienia.

Zasadą pierwszeństwa dobra odbiorcy - co znaczy, że podstawowe prawa czytelników, widzów, słuchaczy są nadrzędne wobec interesów redakcji, dziennikarzy, wydawców, producentów i nadawców.

Zasadą wolności i odpowiedzialności - co znaczy, że wolność mediów nakłada na dziennikarzy, wydawców, producentów, nadawców odpowiedzialność za treść i formę przekazu oraz wynikajace $z$ nich konsekwencje. 
Milewicza w Iraku (Oświadczenie z maja 2004 r.) oraz relacjonowania sensacyjnych wydarzeń (Oświadczenie z 9 listopada 2004 r.)

\section{Etyka mediów w refleksji teologicznej}

W ostatnich latach Kościól kilkakrotnie poruszal zagadnienia dotyczące etyki mediów ${ }^{14}$. Uzasadnieniem tych wystapień jest wskazanie na konieczne zaangażowanie Kościola w te sprawy, które wiążą się z godnością czlowieka i wielowiekową troską o jego postawy moralne ${ }^{15}$. Powolujacc się na podstawy chrześcijańskiej wiary, Kościól wskazal na etyczne zasady, jakimi powinny kierować się media. Podstawowym zadaniem mediów jest powolanie by slużý ludzkiej godności, pomagając ludziom dobrze żyć i uczestniczyć jako osoby w życiu spoleczności (ESP 6). W centrum wszystkich etycznych rozważań stoi czlowiek i jego dzialanie. Na jego decyzje maja wplyw wielorakie czynniki: ekonomiczne, techniczne, polityczne, które w różnym stopniu wplywają na wszystkie plaszczyzny tworzenia przekazu, jak produkcja, dystrybucja i odbiór. To wpisanie aktu dzialania czlowieka w calość struktury i techniki medialnej tworzy szczególną trudność w poszukaniu porozumienia dotyczącego etycznej oceny procesów medialnych. Obecność techniki i fascynacja jej możliwościami nie oznacza jednak, że jej instrumenty wymknęly się spod kontroli czlowieka. Media niczego nie robiq samorzutnie - sq instrumentami, narzędziami stosowanymi tak, jak ludzie chcq je stosować (ESP 4). Podstawową etyczną zasada, jaką powinny kierować się, tak system medialny jak i jego uczestnicy, jest czlowiek i jego godność urzeczywistniana w ludzkiej społeczności. Podstawowy problem etyczny jest następujacy: ludzka osoba i spoleczność sq celem i miarq stosowania środków spolecznego przekazu; komunikacja powinna przebiegać od osoby do osoby i shuzyć integralnemu rozwojowi osób (...). Osoby obdarzone sq niezbywalna godnościq i wartościq, których nigdy nie wolno naruszać w imię interesów grupowych (ESP 21). Szacunek dla ludzkiej godności konkretyzuje się w dziennikarskiej pracy poprzez budowanie ludzkiej tożsamości i zgody międzyludzkiej. Specyficznym polem dzialania jest slużba komunikacji, polegająca na odpowiedzialnym wyborze, opracowaniu i przedstawieniu informacji. Wobec coraz bardziej rozwijających się form komunikacji ważne jest również znaczenie samodzielności, odpowiedzialności w korzystaniu z mediów, czyli troska o medialną kompetencję. $\mathrm{Na}$ plaszczyźnie politycznej, z jednej strony potrzeba kontrolowania wplywu mediów na spoleczeństwo, z drugiej zaś możliwie szerokiego dostępu do wolnej informacji grup i spoleczeństw. Wzrastająca globalizacja, także w sektorze mediów, nie może skutkować powstawaniem obszaru wolnego od uregulowań etycznych i prawnych.

\footnotetext{
${ }^{14}$ Papieska Rada ds. Środków Spolecznego Przekazu: Etyka w reklamie 1997 [ER], Etyka w środkach spolecznego przekazu [ESP] 2000 , Etyka w Internecie [EI] 2002.

${ }^{15}$ Etyka w Internecie, pkt 2.
} 
Kościół w swojej refleksji nie precyzuje, jaką wybrać drogę i instrumenty, aby osiagnąc zamierzony cel. Wklad teologii to profetyczno-krytyczny glos w dyskusji na temat stanu i przyszlego ksztaltu mediów, szczególnie w sytuacjach naruszania ludzkiej godności i prawa przynależnego każdemu czlowiekowi. Cytowany dokument „Etyka w środkach spolecznego przekazu” zawiera caly szereg uwag i ostrzeżeń, m.in. dotyczących treści naruszających ludzką godność, takich jak rasistowskie wypowiedzi, obrazy propagujące przemoc i pornografię. Dla ludzkiej spoleczności niebezpieczeństwem jest żądza zysku i dyktat rynku, zwlaszcza wtedy, kiedy zrodzone z neoliberalizmu, stają się jedynymi normami regulującymi wspólżycie ludzkiej spoleczności. Kolejnym globalnym problemem staje się opóźnienie komunikacyjne krajów trzeciego świata, indoktrynacja, medialny kolonializm i brak poszanowania rodzimej kultury i religii (ESP 14-18).

Wiarygodność tych etycznych postulatów jest uzależniona od samego Kościoła, o ile on sam podejmuje odpowiedzialność za tworzenie i rozwój kultury mediów w slużbie godności czlowieka. Przede wszystkim praktyka spolecznego przekazu w samym Kościele musi być przykladna i nienaganna, stosować się do najwyższych standardów prawdomówności, odpowiedzialności, wrażliwości na prawa czlowieka oraz innych obowiqzujacych zasad i norm (ESP 26). Nie trzeba przekonywać, że jest to problem, który nie podważając sluszności wysuwanych postulatów etycznych, może wplywać na wiarygodność Kościoła jako jednego u uczestników systemu mediów. 
